Yu. M. Kolesnyk, T. V. Ivanenko, A. V. Abramov, N. V. Kuzo

\title{
Current methods of the modeling of experimental diabetes mellitus type 2: a literature review
}

\author{
Zaporizhzhia State Medical University \\ Key words: Diabetes Mellitus Type 2, Experimentation Animal, Insulin Resistance.
}

Background. Diabetes mellitus (DM) became a major problem of the healthcare in Ukraine. The rapid increase in the incidence was noticed especially in recent decade. The treatment of diabetes and its complications become a difficult task. From this standpoint the experimental modeling of diabetes is rather essential. Using the experimental models gives the possibility to assess the significance of the activity of pharmacological substances or to find out new mechanism in the action of medicaments.

The aim of this review is to light up the most studied and common experimental models of diabetes mellitus type 2 (T2DM) in small rodents and find out their drawbacks. It is known the background of T2DM is the violation of the insulin homeostasis such as the resistance of peripheral tissues to insulin as well as the dysfunction of the pancreatic beta-cells, which both lead to appearance of such phenomena as the glucosetoxicity and the lipotoxicity. In the end they both could result in life threatening vascular complications. Considering the steady growth of T2DM patients, the development both of the drug and non-drug methods of its treatment with the high therapeutically efficiency and the perfect safety profile becomes essential. The most important stage of the search of new ways of influence on pathogenetic links of T2DM is the preclinical stage. From this standpoint the usage of experimental models of T2DM has a huge importance. There are a lot of models of T2DM developed by different scientists. These models could be spontaneous or be induced by different chemical diabetogenic substances, diet or surgical interventions or be a combination of methods listed above.

Conclusions. We should underline the adequate modeling of DM2T is the necessary basis for the pre-clinical study of drug-based and not-drug methods of correction of the hyperglycemic states. Using different models makes it possible for infer the obtained experimental results to the society, which suffers from DM2T.

\section{Сучасні методи моделювання експериментального цукрового діабету 2 типу}

\section{Ю. М. Колесник, Т. В. Іваненко, А. В. Абрамов, Н. В. Кузьо}

Цукровий діабет значно поширився в Україні, особливо в останнє десятиріччя. Спостерігається швидке зростання захворюваності. Лікування цукрового діабету та його ускладнень $є$ надважким завданням. У зв'язку з цим важливе значення має моделювання цукрового діабету в експерименті, це дає змогу вірогідно виявляти наявність тієї чи іншої фармакологічної активності препаратів або нових деталей у механізмі дії лікарських засобів.

Мета роботи - знайомство, аналіз і пошук недоліків у доволі вивчених і популярних моделях цукрового діабету 2 типу, котрі впроваджуються на дрібних гризунах (мишах і щурах). Відомо, що в основі цукрового діабету 2 типу лежить порушення інсулінового гомеостазу, зокрема резистентність до інсуліну периферичних тканин і дисфункція бета-клітин підшлункової залози, що призводить надалі до виникнення патологічних феноменів глюкозотоксичності, ліпотоксичності та, в кінцевому підсумку до розвитку небезпечних для життя судинних ускладнень. Враховуючи неухильне зростання кількості хворих на цукровий діабет 2 типу, актуальною проблемою $є$ розроблення медикаментозних та немедикаментозних методів його лікування з високою терапевтичною активністю та досконалим профілем безпеки. Найважливішим етапом пошуку нових методів впливу на патогенетичні ланки цукрового діабету 2 типу є їхнє доклінічне дослідження. У зв'язку з цим велике значення має використання експериментальних моделей цукрового діабету 2 типу, що дають можливість вірогідно виявляти наявність тієї чи іншої терапевтичної активності або нових деталей у механізмі дії лікарських засобів. Ученими розроблена велика кількість моделей цукрового діабету 2 типу. Ці моделі можуть бути отримані спонтанно, індуковані хімічними діабетогенними речовинами, дієтичними або хірургічними маніпуляціями або поєднанням цих способів.

Висновки. Слід відзначити, що адекватне моделювання діабету 2 типу є необхідною основою для доклінічного вивчення медикаментозних та немедикаментозних методів корекції гіперглікемічних станів, а використання різноманітних моделей дає можливість для обгрунтованої екстраполяції результатів, що отримані в експерименті, на людей, які страждають на діабет 2 типу.

Ключові слова: иукровий діабет 2 типу, експерименти на тваринах, інсулінорезистентність.

Патологія. - 2016. - №1 (36). - С. 10-14

\section{Современные методы моделирования экспериментального сахарного диабета 2 типа}

Ю. М. Колесник, А. В. Абрамов, Т. В. Иваненко, Н. В. Кузьо

Сахарный диабет имеет широкое распространение в Украине, особенно в последнее десятилетие: определяется исключительно быстрое повышение заболеваемости. Лечение сахарного диабета и его осложнений является очень тяжёлым заданием. В этой связи большое значение имеет моделирование сахарного диабета в эксперименте, что позволяет достоверно определять наличие той или иной фармакологической активности препаратов или новых деталей в механизме действия лекарственных препаратов.

Цель работы - знакомство, анализ и поиск недостатков в хорошо изученных и популярных моделях сахарного диабета 2 типа, которые внедряются на мелких грызунах (мышах и крысах). Известно, что в основе сахарного диабета 2 типа лежит нарушение инсулинового гомеостаза, в том числе резистентность к инсулину периферических тканей и дисфункция бета-клеток поджелудочной железы, что приводит в дальнейшем к возникновению патологических феноменов глюкозотоксичности и липотоксичности и, в конечном итоге, к развитию угрожающих сосудистых осложнений. Учитывая неуклонный рост числа

(C) Yu. M. Kolesnyk, T. V. Ivanenko, A. V. Abramov, N. V. Kuzo, 2016 
больных сахарным диабетом 2 типа, актуальной является проблема разработки медикаментозных и немедикаментозных методов его лечения с высокой терапевтической эффективностью и совершенным профилем безопасности. Важнейшим этапом поиска новых способов воздействия на патогенетические звенья сахарного диабета 2 типа является их доклиническое изучение. В связи с этим огромное значение имеет использование экспериментальных моделей сахарного диабета 2 типа, которые позволяют достоверно определять наличие той или иной терапевтической активности или новых деталей в механизме действия медикаментов. Учёными разработано большое количество моделей сахарного диабета 2 типа. Эти модели могут быть получены спонтанно или быть индуцированными химическими диабетогенными веществами, диетическими или хирургическими манипуляциями или комбинацией этих способов.

Выводы. Стоит подчеркнуть, что адекватное моделирование диабета 2 типа является необходимой основой для доклинического изучения медикаментозных и немедикаментозных методов коррекции гипергликемических состояний, а использование разнообразных моделей даёт возможность для обоснованной экстраполяции полученных в эксперименте результатов на людей, страдающих от сахарного диабета 2 типа.

Ключевые слова: сахарный диабет 2 типа, эксперименты на животных, инсулинорезистентность.

Патология. - 2016. - №1 (36). - С. 10-14

B ackground. Diabetes mellitus (DM) became a major problem of the healthcare in Ukraine. The rapid increase in the incidence was noticed especially in recent decade. According to WHO reports the worldwide number of diabetes patients in 2000 was 175.4 million, and in 2015 it was increased to 245 million [1].

The treatment of diabetes and its complications becomes a difficult task. From this standpoint the experimental modeling of diabetes is rather essential. Using the experimental models gives the possibility to assess the significance of the activity of pharmacological substances or to find out new mechanism in the action of medicaments.

The aim of this review is to light up the most studied and common experimental models of diabetes mellitus type 2 (T2DM) in small rodents and find out their drawbacks.

It is known the background of T2DM is the violation of the insulin homeostasis such as the resistance of peripheral tissues to insulin as well as the dysfunction of the pancreatic beta-cells, which both lead to appearance of such phenomena as the glucosetoxicity and the lipotoxicity. In the end they both could result in life threatening vascular complications.

Considering the steady growth of T2DM patients, the development of both drug and non-drug methods of its treatment with the high therapeutically efficiency and the perfect safety profile becomes essential.

The most important stage of the search of new ways of influence on pathogenetic links of T2DM is the preclinical stage. From this standpoint the usage of experimental models of T2DM has a huge importance. There are a lot of models of T2DM developed by different scientists. These models could be spontaneous or be induced by different chemical diabetogenic substances, diet or surgical interventions or be a combination of methods listed above [2].

One of the earliest methods of T2DM modeling in mice and rats was the partial resection of the pancreas (near $90 \%$ ). The main drawback of this model is, in most cases, the moderate hyperglycemia without significant changes in body weight or insulin levels, which are inherent for T2DM. Thus, in current models the partial pancreatotomy is usually combined with infusion of chemical diabetogenic substance (such as aloxan, streptozotocin and others). Furthermore, the pancreas has abilities for proliferation and regeneration, so these models are usually used during the transplantational studies [3].

Resent years a lot of experimental T2DM models were improved. They could be classified for 2 types: 1) genetical or spontaneous models and 2) non-genetical or induced.

The interesting example of the genetically determined form of the insulin-independent form of DM is the diabetes in obese $\mathrm{C} 57 \mathrm{BL} / \mathrm{KsJ}-\mathrm{db} / \mathrm{db}$ mice. In homozigot state of this gene the obesity occurs. DM in this case is characterized with hyperphagia, polydipsia, polyuria, hyperglycemia, transient hyperinsulinemia and progressive insulin resistant. Drawbacks of this model are the increasing hyperglycemia and significant necrosis of beta cells in the age of 5-8 months. During several weeks the body weight decreases and rodent dies. It depends on beta cell destruction and insufficiency of their proliferation. These facts evidence about diabetes mellitus type 1-like state development [4].

It should be mentioned the genetic models are rather expensive. In this case the most popular are non-genetic models due to their simplicity, low cost and significance of the results $[5,6]$.

In the last decade the models with the induction of the DM2T-like state in adult rodents using chemical substances with diabetogenic cytotoxic action such as streptozotocin (STZ), dexametasone, dithizone or using the violation of character of feeding (for example, treating rodents with high-fat diets) were proposed. Also the combinations of methods listed above were proposed: neonathal STZ models; STZ models with simultaneous or prior administration of nicotinamide; STZ models on the background of a high-fat diet and others. Let's consider some of them.

The STZ neonatal models are usually carried out on Wistar rats using one of the protocols of STZ administration: 1) a single intraperitoneal injection of STZ in dose of $100 \mathrm{mg} /$ $\mathrm{kg}$ of animal weight on the second day after delivery; 2) a single intraperitoneal injection of STZ in dose of $80 \mathrm{mg} /$ $\mathrm{kg}$ of animal weight on the $5^{\text {th }}$ day of life. STZ should be diluted in citrate buffer ( $\mathrm{pH}=4.5)$, and control group should receive the equivalent amount of the diluter. On $28^{\text {th }}$ day after delivery rats should be taken out of mothers. In should be considered using $2^{\text {nd }}$ protocol it is typical to get a significant amount of lethal cases (app. 50\%) during of the first 3 days after STZ administration. In $1^{\text {st }}$ type of STZ administration protocol in rats the acute insulin deficiency diabetes mellitus 
occurs (significant hyperglycemia, hypoinsulinemia and decrease of the insulin amount in the pancreas with high glucagon levels in plasma with its normal amount in the pancreas). The mortality of this method is near $30 \%$. The spontaneous remission was marked in several weeks. It was accompanied with the beta cells regeneration and the glucose and insulin levels in plasma restore to normal conditions. The moderate basal hyperglycemia accompanied with impaired glucose tolerance appears from 8 -week age of rodents. The pancreatic insulin level usually decreased approximately by $50 \%$ without glucagon amount changed. In addition, the glucose induced insulin secretion is significantly decreased in these animals with normal effect of the non-glucose pancreatic secretogens.

Using the $2^{\text {nd }}$ type of protocol more severe form of diabetes occurs. After the relatively short period of the acute insulin deficiency syndrome the significant basal hyperglycemia with impaired glucose tolerance, high levels of glycosylated hemoglobin, significant decrease of insulin levels with the insulin resistance are usually observed. Beginning of the hyperglycemia and decrease of the insulin response to increased glucose plasma levels are observed already during $4^{\text {th }}$ week. It should be mentioned the significance of insulinindependent component during this model in adult rats after neonatal STZ injection also depends on the rats' breed line and diet type. Thus, the degree of diabetes-like metabolic changes in female Sprague-Dawley rats after the diabetes induction on the $2^{\text {nd }}$ day with STZ dose of $80 \mathrm{mg} / \mathrm{kg}$ was equal to $5^{\text {th }}$ day and $90 \mathrm{mg} / \mathrm{kg} \mathrm{STZ}$ effect in Wistar rats. Additionally, a high-fat diet worsens the glucose homeostasis's state in this model.

In conditions of this model of the neonatal STZ insulinindependent diabetes mellitus the specific insufficiency of the glucose insulin response with the normal insulin response for other secretogenes observed. Such violations of beta cells reaction are typical for DM2T. Thus this model could be used for assessment of glucose lowering action of biologically active substances in case of their long-term usage [7].

It seems to be interesting the model of experimental DM2T based on a partial affection of the beta cells in result of repeated administration of low doses of STZ to adult rats [8]. Diabetes is induced by the everyday intraperitoneal administration of ex temporo solution of STZ $(15 \mathrm{mg} / \mathrm{kg}$ of STZ in $1 \mathrm{mM}$ citrate buffer, $\mathrm{pH}=4.5$ ) during 5 days to mature Wistar male rats with 280-300 g weight. Animals starve with free access to water during 16 hours prior to STZ injection. For the following experiments the rats with glycemia level above 7-8 mmole/l and below $11.1 \mathrm{mmole} / \mathrm{l}$ are usually taken. This DM2T model is characterized with partial insulin deficiency with following hyperglycemia but without violation of peripheral insulin resistance [9].

STZ induced diabetes with simultaneous injection of nicotinamide allows to partially protect the beta cells against cytotoxic action of this diabetogenic substance. Rats in 3-month age are treated with nicotinamide intraperitoneally in dose of $230 \mathrm{mg} / \mathrm{kg} 15$ minutes prior to the intraperitoneal injection of $65 \mathrm{mg} / \mathrm{kg}$ of STZ. It results in moderate and stable basal hyperglycemia with approximately $40 \%$ of pancreatic insulin saved. This model is characterized with carbohydrate intolerance and relative insufficiency of the insulin secretion in response to the hyperglycemia, which are combined with preserved secretory response to non-glucose stimuli and secondary insulin resistance development. Thus, this model allows producing the main signs of DM2T in human: they are the insulin secretion and action violations. This allows using this model in the assessment of the hypoglycemic effects of new biologically active substances with different mechanisms of action.

In several cases of preclinical studies of new anti-diabetic drugs, the dexamethasone model of insulin-independent diabetes is used. It is known the high doses of glucocorticoids could produce the violation of secretory activity of beta cells and insulin resistance development. One of the protocols of such models is described below.

This model is reproduced by following actions: Wistar rats in age of 18 months are treated with subcutaneous injections of dexamethasone solution in dose of $0.125 \mathrm{mg} / \mathrm{kg}$ of rats' body weight. During the experiment there were observed the moderate basal hyperglycemia, twofold increase in the insulin and the unsaturated fatty acids plasma levels, impaired glucose tolerance and low sensitivity of peripheral tissues to insulin [19]. Later it was shown the decrease of glucose consumption by adipocytes after the dexamethasone treatment is accompanied by its direct action to the GLUT1 and GLUT4 expression, which leads to insulin resistance development [11]. The suppressing effect of dexamethasone on the secretory activity of beta cells is trusted to be mediated by inactivation of mitochondrial FAD-glycerophosphate dehydrogenase, which is a key enzyme in glucose-induced insulin secretion [12].

Thus, the dexamethasone DM2T model in mature rats allows causing the violations of insulin's secretion and activity, like the nicotinamide/STZ model. In the same time there is another method of dexamethasone administration, namely its injection using the same protocol but in 3-month Wistar rats, which leads to impaired glucose tolerance, insulin resistance, hyperinsulinemia, but not to basal hyperglycemia. Using this method, we can reproduce the pre-diabetes state. It allows us to assess new hypoglycemic substances and study the mechanisms of their action and their influence on the prevention of diabetes development, which could be connected with the improvement of glucose tolerance or with the increase in insulin sensitivity of peripheral tissues.

Recently many researchers reported the treating of rats with a diet with high fat contain could lead to the insulin resistance development [13-15]. Considering the fact that low doses of STZ provoke moderate impairment of insulin secretion, like in late phase of DM2T [16-17], some models were developed, which actually are the combinations of the high-fat diet and the low STZ doses administration. These models appear to be very interesting for pharmacology due to their ability to reproduce the metabolic peculiarities of DM2T, which are typical for humans [17-18]. We describe one of such models below. 
Sprague-Dawley rats with body weight of 160-180 g were on high-fat diet ( $58 \%$ of calories due to fat) during 2 weeks. The control group received common commercial type of food ( $12 \%$ of calories due to fat). In rats of the experimental group it was found the significant increase of the body weight, the glucose basal plasma level, insulin, triglycerides and general cholesterol compared with the control group. Hyperinsulinemia with significant decrease of glucose consumption according to results of the intravenous glucose tolerance test proved the occurrence of insulin resistance. After 2 weeks of high-fat diet in both groups STZ in low dose $(35 \mathrm{mg} / \mathrm{kg}$ ) was injected. In rats of experimental group, the significant hyperglycemia was observed according to STZ injection response. Control group showed the moderate increase of glucose plasma level. The insulin plasma level in rats of the experimental group was lowered to the level of control rats after STZ injection. In addition, in rats of experimental group the triglycerides and cholesterol plasma levels remained elevated. Vice versa, in rats of control group, which were on diet with the normal contain of fats, STZ caused no significant changes in plasma levels of insulin, triglycerides and general cholesterol. Thus, authors concluded this model (of high-fat diet and STZ combination) reproduces the natural pathway of DM2T development with its metabolic features typical to persons with the high risk of DM2T development due to insulin resistance and obesity presence and, thereby, could be used as a DM2T experimental model. Zhang M. et al. in 2008 proposed a stable model of DM2T in Wistar rats (200-250g) using the combination of high-fat diet (4 weeks) and twofold injection of low doses of STZ intraperitoneally (30 mg/kg of body weight) with an interval of 2 weeks [19].

It should be noted that the data mentioned above do not reflect the whole spectrum of the developed DM2T models. Their number is growing, but they are not sufficiently studied. It also should be considered, that each experimental model reproduces only certain pathways of the DM2T pathogenesis and has not got the full compliance with the human's disease development and progress. Therefore, there are a lot of activities all around the world, which are focused on the modification of existing models and creation of new sophisticated models of DM2T which would have the best reflect of metabolic changes typical for human's DM2T.

Conclusions. Considering mentioned above, we should underline the adequate modelling of DM2T is the necessary basis for the pre-clinical study of drug-based and non-drug methods of correction of the hyperglycemic states. Using different models make it possible for infer the obtained experimental results to the society, which suffers from DM2T.

Conflicts of Interest: authors have no conflict of interest to declare.

\section{References}

1. (2016). Ofitsiinyi sait Vsesvitnoi orhanizatsii okhorony zdorovia [World Health Organization]. Retrieved from http:// www.who.int.

2. Srinivasan, K. \& Ramarao, P. (2007). Animal models in type 2 diabetes research: an overview. Indian J Med Res, 125(3), 451-72.

3. Risbud, M. \& Bhonde, R. (2003). Models of pancreatic regeneration in diabetes. Diabetes Research And Clinical Practice, 58(3), 155-165. doi: 10.1016/S0168-8227(02)00103-1.

4. Prochazka, M., Leiter, E., \& Shultz, L. (1987). Effect of immunodeficiency on diabetogenesis in getenocally diabetic $(\mathrm{db} /$ db) mice. J. Immunol., 138, 149-154.

5. Islam, M. \& Loots, D. (2009). Experimental rodent models of type 2 diabetes: A review. Methods And Findings In Experimental And Clinical Pharmacology, 31(4), 249. doi: 10.1358/ mf.2009.31.4.1362513.

6. Spasov, A. A., Voronkova, M. P., Snigur, G. L., Gheplyaeva, N. I., \& Chepurnova, M. V. (2011). Experimentalnaya model sacharnogo diabeta tipa 2 [Experimental model of diabetes mellitus type 2]. Biomedicina, 3, 12-18. [in Russian].

7. Portha, B. \& Kergoat, M. (1985). Dynamics of glucoseinduced insulin release during the spontaneous remission of streptozocin diabetes induced in the newborn rat. Diabetes, 34(6), 574-579. http://dx.doi.org/10.2337/diabetes.34.6.574.

8. Bobkiewicz-Kozłowska, T., Dworacka, M., Kuczyński, S., Abramczyk, M., Kolanoś, R., Wysocka, W. et al. (2007). Hypoglycaemic effect of quinolizidine alkaloids — lupanine and 2-thionosparteine on non-diabetic and streptozotocininduced diabetic rats. European Journal Of Pharmacology, 565(1-3), 240-244.

9. Bonnevie-Nielsen, V., Steffes, M., \& Lernmark, A. (1981). A major loss in islet mass and B-cell function precedes hyperglycemia in mice given multiple low doses of streptozotocin. Diabetes, 30(5), 424-429. http://dx.doi.org/10.2337/ diabetes.30.5.424
10. Novelli, M., Barbera, M., \& Fierabracci, V. (1996). Effect of the age and dexamethasone treatment on insulin secretion from isolated perfused rat pancreas. Diabetol, 1, A124.

11. Buren, J. \& Eriksson, J. (1999). Dexamethasone decreases GLUT 1 and GLUT 4 content in primary cultured rat adipocytes. Diabetol, 42(1), A170.

12. Fabregat, M., Fernandez-Alvarez, J., \& Franco, C. (1999). Dexamethasone-induced changes in FAD-glycerophosphate dehydrogenase expression in human pancreas islets. Diabetol, 42(1), A141.

13. Tanaka, S., Hayashi, T., Toyoda, T., Hamada, T., Shimizu, Y., $\&$ Hirata, M. et al. (2007). High-fat diet impairs the effects of a single bout of endurance exercise on glucose transport and insulin sensitivity in rat skeletal muscle. Metabolism, 56(12), 1719-1728. doi:10.1016/j.metabol.2007.07.017.

14. Zhao, S., Chu, Y., Zhang, C., Lin, Y., Xu, K., Yang, P., et al. (2007). Diet-induced central obesity and insulin resistance in rabbits. Journal of Animal Physiology and Animal Nutrition, 92(1), 105-111. doi: 10.1111/j.1439-0396.2007.00723.x.

15. Flanagan, A., Brown, J., Santiago, C., Aad, P., Spicer, L., \& Spicer, M. (2008). High-fat diets promote insulin resistance through cytokine gene expression in growing female rats. The Journal Of Nutritional Biochemistry, 19(8), 505-513. http:// dx.doi.org/10.1016/j.jnutbio.2007.06.005.

16. Reed, M., Meszaros, K., Entes, L., Claypool, M., Pinkett, J., Gadbois, T., \& Reaven, G. (2000). A new rat model of type 2 diabetes: The fat-fed, streptozotocin-treated rat. Metabolism, 49(11), 1390-1394. doi: 10.1053/meta.2000.17721.

17. Srinivasan, K., Viswanad, B., Asrat, L., Kaul, C., \& Ramarao, P. (2005). Combination of high-fat diet-fed and low-dose streptozotocin-treated rat: A model for type 2 diabetes and pharmacological screening. Pharmacological Research, 52(4), 313-320.

18. Sahin, K., Onderci, M., Tuzcu, M., Ustundag, B., Cikim, G., Ozercan, İ., et al. (2007). Effect of chromium on carbohy- 
drate and lipid metabolism in a rat model of type 2 diabetes mellitus: the fat-fed, streptozotocin-treated rat. Metabolism, 56(9), 1233-1240. doi: http://dx.doi.org/10.1016/j.metabol.2007.04.021.
19. Zhang, M., Lv, X., Li, J., Xu, Z., \& Chen, L. (2008). The Characterization of High-Fat Diet and Multiple Low-Dose Streptozotocin Induced Type 2 Diabetes Rat Model. Experimental Diabetes Research, 2008, 1-9. doi: 10.1155/2008/704045.

\section{Information about authors:}

Kolesnyk Yu. M., MD, PhD, DSci, Professor, Rector of Zaporozhzhia State Medical University, Head of the Department of Pathological Physiology of Zaporizhzhia State Medical University.

Ivanenko T. V., MD, PhD, Senior Lecturer of the Department of Pathological Physiology of Zaporizhzhia State Medical University, E-mail: ivanenko@zsmu.pp.ua.

Abramov A. V., MD, PhD, DSci, Professor of the Department of Pathological Physiology of Zaporizhzhia State Medical University. Kuzo N. V., MD, Lecturer-Intern of the Department of Pathological Physiology of Zaporizhzhia State Medical University.

Відомості про авторів:

Колесник Ю. М., д-р мед. наук, професор, зав. каф. патологічної фізіології, ректор Запорізького державного медичного університету.

Іваненко Т. В., старший викладач каф. патологічної фізіології, Запорізький державний медичний університет,

E-mail: ivanenko@zsmu.pp.ua.

Абрамов А. В., д-р мед. наук, професор каф. патологічної фізіології, Запорізький державний медичний університет.

Кузьо Н. В., викладач-стажист каф. патологічної фізіології, Запорізький державний медичний університет.

Сведения об авторах:

Колесник Ю. М., д-р мед. наук, профессор, зав. каф. патологической физиологии, ректор Запорожского государственного медицинского университета.

Иваненко Т. В., старший преподаватель каф. патологической физиологии, Запорожский государственный медицинский университет, E-mail: ivanenko@zsmu.pp.ua.

Абрамов А. В., д-р мед. наук, профессор каф. патологической физиологии, Запорожский государственный медицинский университет.

Кузьо Н. В., преподаватель-стажист каф. патологической физиологии, Запорожский государственный медицинский университет. 